\title{
DISCRETION TO PROSECUTE FEDERAL CIVIL RIGHTS CRIMES
}

THE highly publicized violence which has at times accompanied the civil rights revolution has exposed to public debate the possibilities of protecting civil rights through federal criminal law. The principal criminal statutes currently available to the federal government, sections 241 and 242 of title 18 of the United States Code, ${ }^{1}$ have frequently been criticized for their lack of utility, since the Supreme Court has placed upon the prosecutor the burden of proving a violation of a "federally created" right with regard to section 241 , and of proving a specific intent to violate the victim's civil rights with regard to section $242 .^{2} \mathrm{New}$ legislation, though it might alleviate the substantive

1. Of the present criminal statutes, only these two are of broad applicability in the area of civil rights. They read:

\section{Conspiracy against rights of citizens}

If two or more persons conspire to injure, oppress, threaten, or intimidate any citizen in the free exercise or enjoyment of any right or privilege secured to him by the Constitution or laws of the United States, or because of his having exercised the same...

They shall be fined not more than $\$ 5,000$ or imprisoned not more than ten years, or both.

Deprivation of rights under color of law

Whoever, under color of any law, statute, ordinance. regulation, or custom, willfully subjects any inhabitant of any State, Territory, or District to the deprivation of any rights, privileges or immunities secured or protected by the Constitution or laws of the United States, or to different punishment, psins, or penalties, on account of such inhabitant being an alien, or by reason of his color, or race, than are prescribed for the punishment of citizens, shall be fined not more than $\$ 1,000$ or imprisoned not more than one year, or both.

18 U.S.C. $\$ 241$ (1958).

Others, such as 18 U.S.C. $\$ 594$ (1958) (intimidation of voters in federal elections). 18 U.S.C. $\$ 243$ (1958) (exclusion of jurors on account of race or color), and 18 U.S.C. $\S 1074$ (Supp. V, 1964) (a statute directed at individuals responsible for church bombings, but jurisdictionally limited to individuals traveling in interstate commerce), are of narrow applicability. This Note will limit itself to the crimes comprehended by 18 U.S.C. $\$ \S 241-$ 42, particularly as to their enforcement on behalf of aggrieved Negroes in the South.

2. See, e.g., Shapiro, Limitations in Prosecuting Cizil Rights Violations, 46 Consent. L.Q. 532 (1961) ; U.S. CoMn'N on CrvIL Rughts, REPoRT (Book 5) 45-54 (1961).

In Williams v. United States, 341 U.S. 70, 81-82 (1951), the Supreme Court determined that "... \$ 241 applies only to interference with rights which arise from the relation of the victim and the Federal Government, and not to interference by State officers with rights which the Federal Government merely guarantees from abridgement by the States." Thus its coverage would seem to be limited to such rights gronted by the federal government as voting in federal elections, protection from involuntary servilude, and statutes passed pursuant to recognized affirmative sources of Congressional authority, such as the commerce clause.

In Screws v. United States, 325 U.S. 91 (1945), the Supreme Court held that in order to maintain a conviction pursuant to $\$ 242$, the prosecution must bear the burden of proving a "specific intent" on the part of the defendant to violate the constitutional rights of his victim; such a construction was deemed necessary to avoid unconstitutional vagueness in the language of the statute. 
weaknesses of the present statutory scheme, cannot effectively deal with the practical obstacles, such as jury prejudice and the difficulty of obtaining evidence, which make full enforcement of the present statutes impossible. These obstacles apparently have accounted for decisions by the Civil Rights Division of the Department of Justice not to prosecute individuals believed to have committed civil rights crimes. This Note will argue that, regardless of these obstacles, the Justice Department's prosecutorial policy is not a matter merely of executive discretion, but that certain standards are required by law, and that the judiciary can assure southern Negroes that the Justice Department will prosecute individuals who have violated their civil rights.

According to a report of the United States Commission on Civil Rights, published in 1961, when the Department of Justice decides whether or not to prosecute apparent violations of section 242 , it considers three principal factors: the credibility of the victim, the nature of the victim's injuries, and the likelihood of conviction. ${ }^{3}$ These factors are not mutually exclusive. The likelihood of conviction depends in part on the victim's credibility, and on the nature of the victim's injuries. Severe and shocking injuries will have a greater tendency to impress a jury, and evidence of protracted abuse may help prove the necessary specific intent. In the South, though, no matter what the victim's credibility or injuries, the likelihood of conviction is low. Grand and petit juries composed of individuals unsympathetic to the cause of the aggrieved Negro and the civil rights movement in general will not often return indictments or convict. ${ }^{4}$ The low likelihood of conviction is the principal justification for the Civil Rights Division's refusal, at least in former years, to institute criminal prosecutions. ${ }^{5}$ Defenders of this policy might argue that repeated unsuccessful

3. U.S. Comm'n on Crvil RIGHTs, op. cit. sipra, note 2 at $62-63$.

The Commission also pointed out that at the investigatory stage, the FBI had been reluctant to pursue investigations of local authorities named in police brutality complaints, because the cooperation of local authorities is frequently needed in other FBI investigations. Id. at 61-62.

4. See, e.g., Mississippi Advisory Committee to the U.S. Conm's on Civil Ricurs, AdAinistration of JUSTICE IN Mississippi 24-25 (1963) ; Shapiro, supra note 2, at 545-46.

Because $\S 241$ creates a felony offense, a prosecution commenced under it must be presented to a grand jury for indictment unless indictment is waived. FED. R. CkrM. P. 7. The offense created by $\S 242$, a misdemcanor, does not require indictment and may be prosecuted on an information. The Civil Rights Division, however, has pursued a policy of prosecuting only those offenses under $\S 242$ where it has been able to obtain an indictment from a grand jury. This policy has been defended in a letter from Burkic Marshall, former head of the Division, to John De J. Pemberton Jr., Executive Director of the American Civil Liberties Union, March 13, 1963, appearing in Hearings Bcforc Subcommittee No. 5 of the House Committee on the Jutdiciary, 88th Cong., 1st Sess, sec. 4, pt. 2. at 1230 (1963). For a more thorough analysis of this policy, see U.S. Consu's on Crvil RigreTs, op. cit. supra note 2, at 64-66. The policy is criticized by Shapiro, sipra at 547.

5. Critics have questioned the appropriateness of this criterion. The Civil Rights Commission felt that the Division had sometimes attached excessive value to the "success" 
prosecutions would promote disrespect both for the particular criminal provisions at issue ${ }^{6}$ and for law generally, by publicizing that the law can be violated with impunity. This argument is not persuasive.

A policy of non-prosecution is much more likely to lead to a disrespect for law, since the policy represents a federal acquiescence in the prejudice and bigotry of the southern social system. And these are the very aspects of that system against which federal law is directed. For the federal government to say, "We will not attempt to enforce our law because the southern social system will not permit it," is to mock the "rule of law," and at least in some measure to lend validity to an illegal social system. If the government bows to southern prejudice and ignores its own laws why cannot those who desire noncompliance with the Supreme Court's desegregation rulings or the Civil Rights Act of 1964 ignore them on the same grounds? In this regard, Professor Black has suggested that if the legal system

... will not insist that legal rights be implemented by normal legal remedies ... the typical citizen hardly feels he is dealing with "law" at all. He cannot show respect for a law that does not respect itself; his respect for law is given no outlet.?

Moreover, publicity of civil rights crimes and their subsequent prosecution, even if unsuccessful, "by disclosing the Government's evidence in a public trial, can have an educative and therapeutic effect upon the entire community." of the legitimate goals, perhaps the most important goal, of the civil rights movement is to open a closed society. ${ }^{8}$ Perhaps it will be necessary to achieve a change in the fundamental values and moral norms of southern communities where the rights of Negro citizens are regularly being violated; or perhaps it will be necessary only to encourage and protect an unvocal majority which already shares the values embodied in civil rights legislation, or which at least abhors violence and is prepared to abide by such legislation. ${ }^{10}$ In cither case, factor in failing to prosecute apparently serious violations. U.S. Cosns'N. on Crvn Rranis, op. cit. supra note 2 , at 63.

In 1963, the Mississippi Advisory Committee to the United States Commission on Civil Rights recommended:

That the President direct the Department of Justice to investigate every allegation of physical abuse of authority by State or local officials in Mississippi, and institute criminal proceedings in all cases in which such action appears warranted, regardless of the prospects of conviction. (Emphasis added.)

Mrssisstppi Advisory Cosar. to the U.S. Cosar'n on CrviL RugBts, op. cit. sipra note 4 , at 27.

6. This argument is suggested by U.S. Coararn on CIrIL Rugris, op. cir. supra note 2 , at 63 .

7. Black, The Occasions of Justice 151 (1963).

8. U.S. Conarin on CIVIL RIGHTS, op. cit. supra note 2, at 63.

9. See generally, Sirver, Mississippr: The Closed Socrety (1964).

10. In speaking to the reaction of southern communities to school integration, Professor Black has stated:

If a court declares that Negro children have a constitutional right to go to school with whites, a southern white may, if he respects the law, prepare himself 
there can be no change if the community is ignorant of a minority's unlawful acts. If the undesirability of publicizing unpunished violations is extended to its necessary conclusion, all publicity concerning unprosecuted civil rights crimes would have to be withheld from the community. This argument denies the rule of reason which lies at the root of our democratic system. A major premise of our system is that society is best served when public issues are subjected to public scrutiny, discussion, and debate. It is difficult to believe that the way to change a closed society is by bedding it down in a blanket of ignorance.

Further, the policy of prosecuting only where conviction is likely is based upon the questionable assumption that one can predict with certainty a jury's verdict. Although the possibility of success might be slight, every highly publicized conviction would serve a deterrent and restraining function. Even an acquittal would serve a deterrent function by exposing a criminal defendant to the ordeal of trial. If this constitutes harassment of a defendant ultimately acquitted, it is not illegal harassment, so long as the Justice Department has cause to believe him guilty. ${ }^{11}$ And if the ordeal of trial serves in any way to deter unlawful actions, it is not only legal but desirable. A continuing threat of prosecution could not fail to have some effect upon local law enforcement officers who are daily in a position to violate section 242 . If the southern sheriff rests secure in the knowledge that the federal government will not prosecute violations of this statute, he may feel free to abuse the atthority of his office. ${ }^{12}$

Recently, it appears that the "probability of conviction" standard has begun to give way to a recognition by the Justice Department that a prosecution can serve a valid function even where no conviction results. ${ }^{13}$ To the extent that

at the least to acquiesce and to support the authority of the court against lawless elements ... [But if the courts postpone the enjoyment of this right,] respect for law can no longer motivate insistence on desegregation, for the court itself is not insisting ... [T] [Te man who might have been moved by it to stupport desegregation even against his own emotional preference is inevitably thrown into tactical alliance with the out-and-out obstructionists.

Black, The Occasions of Justice 151 (1963).

11. "Guilty" as the word is used in the Note does not mean legal guilt in the sense of a jury's conclusion; see Packer, Two Models of the Criminal Process, 113 U. PA. L. REv. 1, 16 (1964). Rather, it means that an individual has actually engaged in the conduct which the criminal statute proscribes.

12. The Mississippi Advisory Committee to the United States Commission on Civil Rights has observed:

[T] he fact that police officers are rarely tried on civil rights charges has led the public to believe that few serious charges are ever made, and has reinforced the belief among offending peace officers that they may treat or mistreat Ncgrocs as their whims direct them.

Mississippi Advisory Comm. to the U.S. Comm'n on Civil Rights, op. cit. supra note 4 at 25 .

13. At a seminar at the Yale Law School, April 21, 1965, Assistant Attorncy General John Doar asserted that the current standard employed by the Civil Rights Division in determining whether to prosecute, is whether a conviction can be obtained from a "fair- 
precise boundaries of the new policy have not yet emerged and that any executive policy is subject to change as personnel changes, the protection accorded southern Negroes by the federal criminal process remains uncertain. Furthermore, other justifications, which at first blush might seem relevant to civil rights, have been advanced in support of the general discretion permitted the Justice Department.

Traditionally, the judiciary has acquiesced in prosecutorial discretion. Policy reasons which have been advanced for allowing federal prosecutors to exercise discretion in determining whether particular prosecutions should be instituted and pursued include: that the prosecutor should be able to pick a "strong" case to test uncertain law; ${ }^{\mathbf{1 4}}$ that federal prosecutors should stand aside in favor of state prosecutions where an individual's conduct has violated both state and federal law, and where the state is willing to prosecute ;6 $^{10}$ that the administrative and financial burdens of prosecuting all criminal violations force the prosecutor to make some decisions not to prosecute $;^{10}$ and that insufficient evidence might justify a decision not to prosecute on the ground that public funds would be expended needlessly. ${ }^{17} \mathrm{~A}$ further justification for judicial acquiescence has been the contention that the political process is sufficient to check excessive abuse of discretion. ${ }^{18}$

minded jury." He agreed with the proposition that unsuccessful prosecutions can serve a valid purpose, at least insofar as the likelihood of convictions will increase with the number of prosecutions.

14. Pugach v. Klein, 193 F. Supp. 630, 635 (S.D.N.Y. 1961).

15. L. Schwartz, Federal Criminal Jurisdiction and Prosecutors' Discrelion, 13 LAw \& Contens. Prob. 64, 70-77 (1948).

16. Pugach v. Klein, 193 F. Supp. 630, 635 (S.D.N.Y. 1961); M. Schwartz, Professional Responsibility and the Adaninistration of Criannal Justice 14 (1961).

In Goldstein, Police Discretion Not to Inzoke the Criminal Process: Lont-Visibility Decisions in the Administration of Justice, 69 YALE L.J. 543, 561 (1960), the author recognizes a similar problem in the exercise of police discretion. The result is "priorities of enforcement" which are determined in part by time, personnel, and other functions of budget.

17. Pugach v. Klein, 193 F. Supp. 630, 635 (S.D.N.Y. 1961); Cf. Cates, Can IVC Ignore Law? - Discretion not to Prosecute, 14 Ala. L. Rev. 1, 6 (1961); in this regard, the opinion of Attorney General Cummings, 38 Ops. ATr'y GEN. 98, 99-100 (1934), quoting Attorney General Taney in 2 OPS. ATT'Y GeN. 486 (1831) is instructive of the Justice Department's position:

An attorney conducting a suit for a party has, in the absence of that party, a right to discontinue it whenever, in his judgment, the interest of his client requires it to be done. If he abuses this power he is liable to the client whom he injures. ... An attorney of the United States, except insofar as his powers may be restrained by particular acts of Congress, has the same authority and control over the suits which he is conducting. The public interest and the principles of justice requirc that he should have this power; for, why should the public be put to the expense of preparing a suit for trial, and procuring evidence, when the attorney lnows that, on principles of law, it cannot be supported? Why should he be required, on behalf of the United States, to harass a defendant with a prosecution, which, pending the suit, he discovers to be unjust and groundless?

18. The efficacy of such checks is denied by MI. Schwartz, op. cit. sipra note 16 , at 34-35; Note, Prosecutor's Discretion, 103 U. PA. L. REv. 1057, 1075-77 (1955). 
The argument that the prosecutor must be given discretion to pick a strong case to test the constitutionality of uncertain laws, if valid at all, has no application where the statutes have been upheld by the Supreme Court. ${ }^{10}$ And the argument that federal prosecutors should have the option to stand aside in favor of state prosecutions obviously has no application when the states systematically fail to prosecute. The third argument, that administrative and financial burdens require some decisions not to prosecute, does not apply to civil rights crimes. In the only authoritative analysis of the prosecutorial policies of the Civil Rights Division, the United States Commission on Civil Rights did not indicate that financial burdens were a factor relevant to determinations not to prosecute. ${ }^{20}$ The Civil Rights Division denied recently that a shortage of appropriations has affected its policies appreciably. ${ }^{21}$ The argument that insufficient evidence justifies a decision not to prosecute is persuasive insofar as the evidence is so insufficient that it would not sustain a conviction as a matter of law. To compel a government attorney to prosecute upon stich evidence might be to compel an act which would deny the alleged criminal due process of law by subjecting him to unsupportable harassment. And finally, it seems clear that the political process, especially in the South, cannot check excessive abuse of prosecutorial discretion. Some critics have suggested that the political nature of most prosecutorial officers actually increases the danger of unfettered discretion. ${ }^{22}$

Regardless of these policy arguments, the federal courts, basing their decisions upon a separation of powers theory, have uniformly permitted United States attorneys absolute discretion both in bringing ${ }^{23}$ and dismissing criminal prosecutions. ${ }^{24}$ This judicial response is illustrated by the recent case of

19. Although the scope of $\$ 242$ was severely limited by the Supreme Court in Screws v. United States, 325 U.S. 91 (1945), it was sufficiently delineated to notify future prosecutors of the section's requirements, and its validity. Section 241 was similarly delineated and declared constitutional in Williams v. United States, 341 U.S. 70, 82-83 (1951).

20. U.S. CoMM'N on Civm Rights, REPORT (Book 5) (1961).

21. Statement of Assistant Attorney General John Doar at a seminar at the Yale Law School, April 21, 1965.

22. See Note, Prosecutor Indiscretion: A Result of Political Influence, 34 INn. L.T. 477 (1959).

23. See Goldbèrg v. Hoffman, 225 F.2d 463 (7th Cir. 1955) ; Pugach v. Klein, 193 F. Supp. 630 (S.D.N.Y. 1961); Howell v. Brown, 85 F. Supp. 537 (D. Neb. 1949); Millikin v. Stone, 7 F.2d 397 (S.D.N.Y. 1925). Cf. Parker v. Kennedy, 212 F. Supp. 594 (S.D.N.Y. 1963).

24. See, e.g., Confiscation Cases 74 U.S. (7 Wall.) 454 (1868); United States v. Woody, 2 F.2d 262 (D. Mont. 1924).

A case particularly illustrative of the scope of this discretion is Unitcd States v. Brokaw, 60 F. Supp. 100 (S.D. Ill. 1945). Where two of three defendants had pleaded not guilty of the commission of a particular crime and the third defendant pleaded guilty, the district attorney was permitted to enter a nolle prosequi as to the third defendant because he felt there was insufficient evidence to procure convictions of the first two. The court held that United States attorneys are charged with the same duties as the attorncy general under English common law and are thus vested with discretion beyond the reach of the courts. 
United States v. Cox, ${ }^{25}$ in which a United States attorney refused to prepare and sign indictments for perjury after being requested to do so by a legally constituted grand jury. ${ }^{26} \mathrm{~A}$ majority of the Fifth Circuit held that signing the indictment was completely discretionary :?T

Although as a member of the bar, the attorney for the United States is an officer of the court, he is nevertheless an executive official of the Government. . . . It follows, as an incident of the constitutional separation of powers, that the courts are not to interfere with the free exercise of the discretionary powers of the attorneys of the United States in their control over criminal prosecutions. (Emphasis added.) ${ }^{28}$

Significantly, even those judges who thought that determining whether to sign the indictment was not within the discretion of the prosecutor felt constrained to add:

$[O]$ nce the indictment is returned, the Attorney General or the United States Attorney can refuse to go forward.... To permit the district court to compel the United States Attorney to proceed beyond this point would invest prosecutorial power in the judiciary, power which under the Cossstitution is reserved to the executive branch of the government. (Emphasis added.) ${ }^{29}$

Any judicial attempt to regulate criminal prosecutions under civil rights statutes must thus address itself to one of the most perplexing questions in our criminal law: can a court, consistently with the constitutional limitations placed upon it by the separation of powers doctrine, compel an executive officer to prosecute? If the courts are bound by the traditional doctrine of prosecutorial discretion, the conclusion is inescapable that the Civil Rights Division cannot be limited by the judicial branch in its application of the probability of conviction standard.

An ineffectual and misguided challenge to the doctrine of prosecutorial discretion as applied to civil rights crimes has recently been made. In MLoses $v$.

25. 342 F.2d 167 (5th Cir. 1965), cert. denied, 33 U.S.L. WeER 3388 (U.S. June 1, 1965).

26. This was an action by government attorneys who sought a writ of prohibition to prevent the district judge from holding the United States attorney in contempt of court for refusing to prepare and sign the indictment Judge Brown agreed with the holding of Judge Jones, joined by Chief Judge Tuttle and Judge Wisdom, that the United States attorney acted within his permissible discretion in refusing to sign the indictment. He joined Judges Rives, Gewin and Bell, however, in holding that the United States attorney was required to serve as the grand jury's scrivener in preparing the indictment because he was the only legal counsel available to it.

27. FED. R. CRIN. P. 7(c) was held not to preclude discretion. That Rule states: "It [the indictment] shall be signed by the Attorney for the Government"

28. $342 \mathrm{~F} .2 \mathrm{~d}$ at 171.

29. Id. at 179. After the indictment has been signed, the United States attorney masenter a nolle prosequi pursuant to FED. R. CRnr. P. 48(a). The words, "by leave of court," in the Rule have been held not to act as a check on his discretion unless it appears "clearly and convincingly" that the public interest requires judicial intervention. United States v. Greater Blouse, Shirt \& Neckwear Contractors Ass'n., 228 F. Supp. 483, 486 (S.D.N.Y. 1964). 
Kennedy, ${ }^{30}$ eight alleged victims of civil rights crimes, seven of them Negroes, sought mandamus directing the United States Attorney General and the Director of the Federal Bureau of Investigation to arrest, and to institute criminal prosecutions against, an unspecified class of individuals ${ }^{31}$ allegedly responsible for the deprivation of their constitutional and statutory rights. In support of their request plaintiffs sought to invoke section 1987 of title 42 of the United States Code, a descendant of the Civil Rights Act of $1866^{.22}$ In its current form, section 1987 reads :

The United States attorneys, marshals, and deputy marshals, the commissioners appointed by the district and territorial courts, with power to arrest, imprison, or bail offenders, and every other officer who is especially empowered by the President, are authorized and required, at the expense of the United States, to institute prosecutions against all persons violating any of the provisions of section 1990 of this title or of sections 5506-5516 and 5518-5532 of the Revised Statutes, and to cause such persons to be arrested, and imprisoned or bailed, for trial before the court of the United States or the territorial court having cognizance of the offense. (Emphasis added.) ${ }^{33}$

The court refused to issue mandamus, following the separation of powers and prosecutorial discretion doctrines. District Judge Youngdahl, rejecting plait1tiff's reliance on the statutory phrase "authorized and required," held that section 1987 did not alter the traditional doctrine.

Nothing in the legislative history . . . suggests that this statute should be construed more broadly than any other as far as limitations upon the power of the Judiciary to force the Executive to act are concerned. In*

30. 219 F. Supp. 762 (D.D.C. 1963), aff'd per curiam sub nom. Moses v. Katzenbach, Civil No. 18065, (D.C. Cir., Feb. 16, 1965).

31. The complaint merely identifies the alleged offenders in such terms as "local law enforcement officers" of specified towns, "city policemen" in Jackson, Mississippi, and "a group of citizens which included county officials" in Liberty, Mississippl. 219 F. Supp. at 766 n. 2.

32. 14 Stat. 28 (1866).

33. Sections 5506-5516 and 5518-5532, referred to in this statute, have been repealed in part and are otherwise presently set forth in $\$ \S 241,242,372,592,593,752,1071,1581$, 1583 and 1588 of Title 18, Crimes and Criminal Procedure (1958). Sections 241 and 242 are the only statutes directly germane to the problem with which this Note is concerned; they are set out in note 1, supra. The remaining sections of the Criminal Code comprehended by $\S 1987$ are directed against such crimes as "conspiracy to impede or injure officer" ( $\$ 372)$; "instigating or assisting escape" (\$ 752); "concealing person from ar" rest" ( $\$ 1071)$; "peonage" ( $\$ 1581)$; "enticement into slavery" (\$ 1583); and "transpor" tation of slaves from United States" ( $\$ 1588)$. 42 U.S.C. $\$ 1990$ (1958), also comprehended by $\S 1987$, provides penalties for federal marshals who refuse to execute warrants for the arrest of civil rights offenders.

U.S. Comm'N on Civir Rrgers, op. cit. supra note 2 at 64 , has found that the control of all civil rights cases rests with the Attorney General and the Civil Rights Division, although United States attorneys usually assume the responsibility for the presentation of the cases. Thus plaintiffs were well-advised to seek an order directed at the Attorncy General, although it probably would have also been advisable to join the local Unitcl States attorney from Mississippi as a party defendant, if service were possible. 
deed, such considerations of judgment and discretion apply with special strength to the area of civil rights, where the Executive Department must be largely free to exercise its considered judgment on questions of whether to proceed by means of prosecution, injunction, varying forms of persuasion, or other types of action. ${ }^{34}$

The court's treatment of section 1987 and its discussion of separation of powers - and the two are intimately related - leaves much to be desired. Certainly the legislature can, consistently with separation of powers, regulate the activity of the executive. And it is the duty of the courts to compel executive compliance with the legislative will. As early as 1803, Marbury v. Madison established that,

where a specific duty is assigned by law, and individual rights depend upon the performance of that duty ... the individual who considers himself injured, has a right to resort to the laws of his country for a remedy. ${ }^{35}$

The decisions invoking the doctrine of prosecutorial discretion, permitting the entrance of a nolle prosequi and denying mandamus, are all predicated upon the assumption that the legislature granted discretionary power to federal prosecutors. A court which directs these prosecutors to act invades the province of the executive. But where Congress has specifically directed executive conduct, a court violates no constitutional principle by ordering compliance with the statute. ${ }^{36}$ Thus, the Supreme Court has observed,

[I]t would be an alarming doctrine, that congress cannot impose upon any executive officer any duty they may think proper, ... and in such cases, the duty and responsibility grow out of and are subject to the control of law ... And this is emphatically the case, where the duty ... is of a mere ministerial character. (Emphasis added.) ${ }^{37}$

"Ministerial" and "discretionary" are conclusionary terms. Whether a prescribed act is one or the other depends upon congressional intent. ${ }^{33}$ Section 5 of the Pure Food and Drug Act of 1906 provided that upon the Secretary of Agriculture's report of a violation, it became "the duty" of the district attorney

34. $219 \mathrm{~F}$. Supp. at 765. The court found additional support for its holding in the ambiguity of the relief requested by the complaint, namely, that plaintiffs had specificd no individuals against whom they wished prosecutions to be instituted.

35. 5 U.S. (1 Cranch) 137, 166 (1803).

36. In the Confiscation Cases, 74 U.S. (7 Wall.) 454 (1868), relied upon by virtually all federal courts which have invoked the doctrine of prosecutorial discretion, the Supreme Court recognized the possibility that Congress could take discretion away from the prosecutor. Justice Clifford stated:

Public prosecutions, until they come before the court to which they are returnable, are within the exclusive direction of the district attorney . . . except in cases zohere it is otherwise provided in some act of Congress.

74 U.S. (7 Wall.) at 457. (Emphasis added.)

In Harris v. Settle, 322 F.2d 908 (8th Cir. 1963) where a Negro claimed that federal prison authorities had deprived him of his civil rights, the court was able to avoid reaching the issue of whether $\S 1987$ granted the prosecutor discretion by holding that the acts complained of did not violate the Constitution or laws of the United States.

37. Kendall v. United States, 37 U.S. (12 Pet.) 522, 610 (1838).

38. See, e.g., Kendall v. United States, supra note 37; Wilbur v. United States ex rel. Kadrie, 281 U.S. 206 (1930). 
"to cause appropriate proceedings to be commenced and prosecuted." Tho The Supreme Court recognized that United States attorneys were compelled by this statute to institute criminal prosecutions. ${ }^{40}$

It becomes apparent, therefore, that the separation of powers rationale of the Moses court hinges entirely upon its interpretation of section 1987. The court's rather summary treatment of this section is inadequate and unpersuasive. It simply is not true to say that "nothing in the legislative history . . . suggests that this statute should be construed more broadly than any other," for there are such suggestions.

From an examination of the pages of the Congressional Globe which report the debates prior to the enactment of the original statute no firm conclusion can be drawn concerning the intended meaning of the phrase "authorized and required."41 But from an examination of the political context in which the Civil Rights Act of $1866^{42}$ became law a more helpful reading of the Reconstruction Congress' intent may be made. Congress was well aware that President Andrew Johnson staunchly opposed the proposed legislation. Anticipating that the President might frustrate its purpose, Congress attempted to circumvent the executive partially by providing enforcement procedures. In three provisions Congress intruded into traditionally executive domain. ${ }^{43}$ Criminal penalties

39. 34 Stat. 768, 769 (1906).

40. In United States v. Morgan, 222 U.S. 274, 281 (1911), the Court said:

[After the procedural requirements of the act have been fulfilled] ... the district attorney is compelled to prosecute without delay. When he receives the Secretary's report, he is not to make another and independent examination. . . . [T] The statuto compels him to act....

41. The briefs written by both sides which were submitted to the appellate court in the Moses case are indicative of arguments that might be made on either side of the issuc.

Thus appellees pointed to a statement by one of the original bill's supporters, Congressman Thayer, who had said: "The Bill seeks to enforce these rights in the same manner and with the same sanctions under and by which other laws of the United States arc enforced." Cong. Gzobe, 39th Cong., 1st Sess. 1153 (1866). Since the Confiscation Cases, sipra note 37 , had already established the doctrine of prosecutorial discretion, they argued, Congressman Thayer's statement indicated an intention to incorporate that manner of enforcement. Brief for Appellees, pp. 21-22, Moses v. Katzenbach, Civil No. 18065, (D.C. Cir. Feb. 16, 1965). They also argue (at p. 23), that President Johnson's long and detailed veto message CoNG. Grobe, supra at 1679 , declared no objection to a denial of prosecutorial discretion in the fourth section of the bill; since he was strentously opposed to its passage he certainly would have objected to that section had he felt it created such a severe departure from prior practice.

Appellants' brief pointed to numerous places throughout the debates where the words "require" and "duty" were used, words which in themselves would seem to indicate more than a mandate to be invoked in the exercise of discretion. Brief for Appellants, pp. 6-8, Moses v. Katzenbach, Civil No. 18065, (D.C. Cir. Feb. 16, 1965). Appellants further urged (at pp. 9-10) that a subsequent civil rights act of 1875, 18 Stat. 335, which incorporated the same language as is present in $\$ 1987$ and which provided for specific liability for "any district attorney who shall wilfully fail to institute and prosectute the proceedings herein required," indicates that the meaning of the words "authorized and required" is directory rather than discretionary.

42. 14 Stat. 27 (1866).

43. See veto message of President Andrew Johnson, Cong. Grone, 39th Cong, 1st Sess. 1679 (1866). 
were provided for marshals who refused to execute warrants issued pursuant to the Act. District courts were empowered to appoint persons other than marshals to execute warrants and make arrests. These "court appointed marshals" were empowered to call to their aid such portions of the army and navy "as [was] necessary for the performance of the duty with which they [were] charged." In 1889, a court clearly recognized the purpose of these provisions.

The United States marshals, being presidential appointees, and the hostility of Mr. Johnson to the civil rights bill being notorious, it was apprehended that the marshals would not enforce the law. ${ }^{25}$

Government attorneys were also presidential appointees normally subject to his direction. Therefore, if Congress feared presidential frustration of its purpose - and it is unlikely that the purpose of the Act could be effectuated without the prosecution of offenders - it would not seem unwarranted to conclude that when Congress said "authorized and required" it meant that prosecution was to be mandatory. ${ }^{46}$ When the Moses court concluded that section 1987 allowed special deference to executive "judgment and discretion," it betrayed an extreme insensitivity to the statute's historical parentage. For the soul and substance of the Civil Rights Act of 1866 was to grant protection to Negroes in the South - certain, not contingent, protection.

In effect the Moses court interpreted section 1987 out of existence. For unless the section is construed to be directory rather than a discretionary grant of power, the statute does nothing more than provide United States attorneys with discretionary authority which they have already under the statute which defines their duties, section 507 of title 28 of the United States Code. ${ }^{47}$ Courts usually prefer constructions of statutes which do not render them redundant. ${ }^{48}$ Only the mandatory reading of section 1987 will avoid redundancy. ${ }^{40}$

44. 14 Stat. 28 (1866).

45. In re Upchurch, 38 Fed. 25, 27 (C.C.E.D.N.C. 1889).

46. An opposite conclusion might be reached on the basis of Congress' failure to provide criminal penalties and court appointed replacements for renegade district attomeys as it had for marshals. This interpretation is not persuasive since it is based solely upon legislative silence.

47. 28 U.S.C. \& 507(a) (1958) provides that:

Except as otherwise provided by law it shall be the duty of each United States attorney, within his district, to: (1) Prosecute for all offenses against the United States....

The courts, relying upon common law doctrine, have consistently interpreted this grant of authority as vesting discretion in federal prosecutors, implicitly interpreting the imperative "it shall be the duty" as not mandatory. See, c.g., Confiscation Cases. 74 U.S. (7 Wall.) 454 (1868) ; United States v. Brokaw, 60 F. Supp. 100 (S.D. Ill. 1945).

48. See, e.g., Singer v. United States, 323 U.S. 338, 344 (1945); Amerian Amusement Co. v. Ludwig, 82 F. Supp. 265, 266 (D. Minn. 1949).

49. This interpretation should also be applicable for the prosecution of crimes not involving civil rights which $\$ 1987$ encompasses, and which are set out fully in note 33 supra.

There is one other reading of $\S 1987$ which might indicate a purpose other than making prosecution mandatory, and still avoid the redundancy presented by the grant 
Even though section 1987 is mandatory, 50 not all aggrieved individuals will succeed in forcing the Justice Department to prosecute. If the plaintiff alleges facts insufficient to enable a prosecutor to proceed, a court cannot order him to proceed. For example, the complaint in Moses alleged no specific violators, but instead sought to compel proceedings against "white law enforcement officers and private citizens of the state of Mississippi." 62 Obviously, this kind of complaint is ineffective, for even the Civil Rights Division could not comply with such a broad request. Were a court to issue mandamus compelling prosecution of the broad class "offenders" alleged in Moses, the court would

of 28 U.S.C. $\$ 507$ (a). This construction would empower United States commissioners, marshals and deputy marshals with the authority to "institute prosecutions," in the senso of an advocacy role generally reserved to United States attorneys.

Such an interpretation, aside from being unsupported by any legislative history or actual practice, might create constitutional objections, and therefore must be rejected. By virtue of 18 U.S.C. $\$ 3041$ (1958) and FED. R. CRIM. P. 4(a) United States commissioners are vested with the authority frequently invoked as quasi judicial officers, to issue warrants upon a showing of probable cause. If the officer serving as advocate in a criminal prosecution were also the officer empowered to reach a determination of probable cause for the issuance of a warrant, the due process guarantecd to any accused individual would be violated. The Supreme Court stated in Johnson v. United States, 333 U.S. 10, 14 (1948), that the officer issuing a warrant must be "a nettral and detached magistrate." (Emphasis added.) Cf. Wong Sun v. United States, 371 U.S. 471, 481-82 (1963) ; Giordanello v. U.S., 357 U.S. 480, 486 (1958), Tumey v. Ohio, 273 U.S. 510 (1927).

Since commissioners are appointed and may be removed by the district courts which they serve, 28 U.S.C. $\$ 631$ (1958), another due process objection is that permitting the commissioner to act as prosecutor will create too close a nexus betwcen court and prosecutor. Compare United States v. Solomon, 216 F. Supp. 835, 842-43 (S.D.N.Y. 1963).

50. Section 1987 directs United States attorneys "to institute prosectitions." In order to make the statute meaningful, one must read this phrase in more common par* lance, to commence prosecutions and pursue them to their conclusion. For if the phrase is read to revest discretion at any point in the prosecutorial process, the entire directory purpose of the section is defeated.

51. It seems clear that an aggrieved party will have standing to seek vindication in the courts. This is not a situation where a member of society is merely attempting to assert a legal right on behalf of society. Such a view might cast some doutht upon standing. But see, for persuasive counter arguments, Jaffe, Standing to Sccurc Indiciol Review: Public Actions, 74 HARv. L. Rev. 1265 (1961). Nor, despite the traditional debate of whether retribution is a valid purpose of the criminal law, can the right to vindication be questioned under $\S 1987$. Congress clearly indicated in the Civil Rights Act of 1866, 14 Stat. 28, that it sought to ensure vindication for the aggrieved individual by providing that the fine of one thousand dollars levied against a marshal who refused to execute a warrant pursuant to the Act, be paid "to the use of the person upon whom the accuscd is alleged to have committed the offense."

An alternative basis for standing, at least in $\S 242$ cases, would arise out of the right of the aggrieved party and other members of his class (race and commtuity), to protection. But under such a theory, it is likely that a party seeking mandamus would havo to prove a pattern or practice of violations, which could impose an insurmountable evidentiary burden.

52. 219 F. Supp. at 766, n. 2. 
have no means of ascertaining whether the Justice Department officials had complied with the order. Mandamus will not lie to compel official actions which the issuing court cannot possibly supervise. ${ }^{53}$

In order to obtain relief, an aggrieved party would have to specify individuals whose prosecution he seeks to compel. ${ }^{54}$ A showing of evidence which could sustain a conviction of the alleged offender as a matter of law should be necessary and sufficient to support a petition for mandamus. ${ }^{\text {is }}$ In the difficult case where the evidence taken in the light most favorable to the complaining party would support a conviction, but the prosecutor, whether on the basis of conflicting evidence or otherwise, believes the accused to be innocent, the prosecutor can subject the purely legal evidentiary standard to the evaluation of a grand jury. A more stringent evidentiary standard would be undesirable because it would impose upon the usually ill-equipped moving party the burden of gathering detailed evidence, and it might require premature disclosure of evidence prejudicial to the ultimate prosecution of the case. At the same time this minimum standard would discourage plaintiffs from bringing frivolous actions under section 1987. Of course, if at any time after the order to prosecute, newly discovered evidence would make impossible a legally sustainable conviction, the government attorney should be free to request the court to vacate the order. These standards and procedures allow the prosecutor some flexibility, but still subject the decision not to prosecute to the scrutiny of the judicial process. Further, under the suggested procedure, there could be no objection that the accused individual was being denied due process by not being made a party to the proceeding since he would retain the protections afford-

53. This judicial policy, has been enunciated by state courts. See, c.g., State cx rel Beardslee v. Landes, 149 Wash. 570, 271 Pac. 829 (1928); People ex rel. Jansen v. City of Park Ridge, 7 Ill. App. 2d 331, 129 N.E.2d 438 (1955); State ex rel. Rosbach v. Pratt, 68 Wash. 157, 122 Pac. 987 (1912) ; Boyne v. Ryan, 100 Cal. 265, 34 Pac. 707 (1893); Walsh v. Laguardia, 269 N.Y. 437, 199 N.E. 652 (1936); contra, Cimeners v. Sahm, 4 N.Y.2d 400, 151 N.E.2d 832 (1958).

54. See Goodell v. Woodbury, 71 N.H. 378, 52 Atl. 855 (1902), where the court, in upholding the issuance of a writ of mandamus ordering prosecution of offenders of the state prohibition laws, answered defendants' "general course of conduct" argument, by noting that the complaint had alleged specific individuals against whom prosceutions were to be brought.

55. In meeting this burden, plaintiffs could not gain access to the files of F.B.I. investigations. Section 1987 makes no provision compelling the Attorney General to disclose such information, and policy reasons - such as preventing a wholesale publication of evidence which could endanger numerous other prosecutions - dictate that a court not order it. Since the Director of the F.B.I., as a subordinate of the Attorney General, under a valid Justice Department regulation may not disclose such information without the anthorization of the Attorney General, all legal avenues to these investigations would scem to be foreclosed to plaintiffs. See 28 C.F.R. $\$ \S 16.1,16.2$ (1965), the predecessor of which was upheld in United States ex rel. Touhy v. Ragen, 340 U.S. 462 (1951). See also, Butterworth v. United States ex rel. Hoe, 112 U.S. 50, 54 (1884) ("mandamus cvidently will not lie to compel a public officer to do a ... thing which his superior in authority has lawfully ordered him not to do."). 
ed by a preliminary examination before a commissioner ${ }^{60}$ and, when appropriate, indictment by a grand jury. ${ }^{57}$

Even if the plaintiff's burden could be met, the question remains whether criminal prosecution is too general a course of conduct to be required by a court. Because the federal courts have interpreted sections 507 and 1987 as discretionary, and have relied on the separation of powers doctrine, they have not found it necessary to reach this question. But some state courts have refused mandamus on the ground that the order would require such direct supervision of the prosecution as to be administratively infeasible and an improper judicial intervention in the adversary process. ${ }^{68}$

The persuasiveness of this argument is vitiated by the fact that federal courts and administrative agencies frequently supervise the general conduct of individuals without burdening themselves administratively and withott finding it necessary to regulate in detail each act in the course of conduct. For example, the NLRB may issue an order compelling parties to bargain in good faith. ${ }^{60}$ This course of conduct is certainly no less general than the conduct of prosecuting. And federal courts have issued mandamus to compel administrative agencies to hear and decide cases over which the agencies have initially claimed a lack of jurisdiction. ${ }^{60}$ Schemes of supervision such as these recognize that where particular individuals or institutions are best suited to order their own affairs they should be left free to do so, but that the law may demand conformity with certain broad standards nevertheless.

Therefore, if a court issues a mandamus to prosecute in good faith, it does not have to enforce the order through direct supervision of the prosecution. The adversary system requires that the prosecutor determine the legal theories on which he should proceed and the evidence which he should present to the jury. Indeed, for a court to make such determinations would create a nexus between court and prosecutor which might violate the due process clause. Whether a prosecutor has proceeded in good faith should be determined after he disposes

56. Fed. R. CRTM. P. 5(c).

57. FED. R. CRIM. P. 6.

58. Thus, in Boyne v. Ryan, 100 Cal. 265, 267, 34 Pac. 707, 708 (1893), the court stated:

The court granting the writ of mandate could not follow the district attorncy through the case, and see to it that he filed proper pleadings, offered sufficient evidence, made necessary objections to evidence offered by the defendant, used proper arguments and authorities in discussing questions raised before the court or jury, and conducted the trial with reasonable care and diligence.

Accord, State ex rel. Rosbach v. Pratt, 68 Wash. 157, 122 Pac. 987 (1912); contra Goodell v. Woodbury, 71 N.H. 378, 52 Atl. 855 (1902).

59. Cf. Fibreboard Paper Products Corp. v. NLRB, 379 U.S. 203 (1964), Brooks v. NLRB 348. U.S. 96 (1954); NLRB v. Express Publishing Co., 312 U.S. 426 (1941); See also Labor Management Relations Act $\$ 8$ (a) (5), 29 U.S.C. $\S 158$ (a) (5) (1958).

60. See, e.g., ICC v. United States ex rel. Humbolt Steamship Co., 224 U.S. 474 (1912); United States ex rel. Louisville Cement Co. v. ICC, 246 U.S. 638 (1918); American Chain \& Cable Co. v. FTC, 142 F.2d 909 (4th Cir. 1944). Cf. Office Employes Union v. NLRB, 353 U.S. 313 (1957). 
of the case in some way. ${ }^{61}$ To permit judicial scrutiny of the prosecutor's action at the end of the case, and to allow the court to apply broad standards in judging the prosecutor's conduct is consistent with the usual supervision of the executive by judicial order. Of course if the Justice Department does not comply, the court cannot enforce the order itself. But this consideration should not deter the court. Courts have frequently issued orders to executive officers compelling action contrary to executive policy. ${ }^{62}$ In almost every case the order has achieved its purpose in spite of the fact that the court could not effectively enforce it.

In the unlikely case that the prosecutor does not comply with the order in good faith, the issuing court can cite the United States attorney or the Attorney General for criminal contempt. ${ }^{03}$ The Attorney General should be held responsible for the good faith compliance of his subordinates. If direct supervision from Washington is administratively infeasible or if the local United States attorney disobeys his superiors, he alone should be held responsible. Possible violations of the order may be brought to the attention of the court by the party who instituted the mandamus proceeding. ${ }^{\text {os }}$ The court then can direct the private attorney to prosecute the respondent on behalf of the court. ${ }^{\circ 0}$ The burden would be on this "private prosecutor" to prove that the federal official had not acted in good faith by showing that he had conducted himself in a manner intended to obstruct the prosecution at any stage of the process.

There are many stages of the process at which a defiant government attorney could sabotage the prosecution. A refusal to present evidence to the grand jury, or to the petit jury, or a refusal to prepare and sign an information, clearly

61. A failure to secure an indictment should be considered a disposition of the case

62. See, e.g., Noble v. Union River Logging R.R., 147 U.S. 165 (1893); U.S. v. Schurz, 102 U.S. 378 (1880); Wilbur v. United States ex. rel. Krushnic, 280 U.S. 306 (1930).

63. 18 U.S.C. \& 401(3) (1958). Although criminal or civil contempt will lic for disobedience of a writ of mandamus, In re Delegado, 140 U.S. 586 (1S91), civil contempt would not serve a useful purpose here, since the complaining party could not prove damages, and equitable relief will have already failed. A government attorney cited for criminal contempt is subject to fine and imprisonment, just as any other attorney practicing before the bar. In re Sylvester, 41 F.2d 231 (S.D.N.Y. 1930).

64. United States Connr's on Civil Rights, op. cit. sipra note 20, at 64, in noting the political nature of the office of United States attorney, made the following finding:

Certain U.S. attorneys ... . have consistently opposed the prosecution of police brutality cases. This opposition has been expressed in protracted delays in prosecution authorized by the [Civil Rights] Division, in halfhearted presentation of eases, and in ignoring the Divison's repeated requests for information concerning the status of the prosecution.

Thus it is obvious that the authority of a court order might not in itself suffice to remedy the laxness of certain United States attorneys. An order directed at the policy-maling officials in Washington, however, could serve to force greater control by the Civil Rights Division over the prosecutorial policies of local government attorneys.

65. Kienle v. Jewel Tea Co, 222 F.2d 98, 100 (7th Cir. 1955).

66. FEd. R. Crñr. P. 42(b); McCann v. New York Stock Exchange, 80 F.2d 212 (2d Cir. 1935). 
would constitute contempt per se. An allegation of bad faith presentation of evidence to the grand or petit jury would present more difficult problems of proof. But the court would have access to the grand jury record, and where no indictment was returned the court could determine at its own initiative whether the prosecutor had acted in good faith. Alternatively, the court might disclose the grand jury record to the attorney for the complainant, since "after the grand jury's functions are ended, disclosure is wholly proper where the ends of justice require it." grounds for contempt. ${ }^{68}$.

Since a court would probably be very reluctant to punish a government attorney for criminal contempt it might issue a reprimand instead. ${ }^{60}$ The reprimand would serve some of the same functions as the penalty. The national publicity resulting from a judicial reprimand would inform the general public of any inappropriate policies and illegal acts of the Justice Department. If this inaction is caused by congressional policies, rather than by prosectutorial misconduct, this too should be known by the public. At the very least, applying section 1987 would expose to the scrutiny of the political process the impediments to invoking the criminal law as a means of protecting civil rights.

In an era when the extension of civil rights to all citizens has become one of the primary goals of our society, the federal criminal law, if enforced, can help to secure and protect these rights. At present, there are indications that the Civil Rights Division is embarking upon an overdue policy of vigorously enforcing this law. Under section 1987 courts are competent to ensure that there will be no avoidance of or retreat from full enforcement. The judiciary need not tolerate an enforcement policy acquiescing in the bigotry of the southern social system.

67. United States v. Socony-Vacuum Oil Co., 310 U.S. 150, 233-34 (1940).

68. Once a jury has been empanelled, deliberate precipitation of a mistrial or any other misconduct at the trial stage will preclude further prosecution, because of the constitutional prohibition of double jeopardy. Cf. Downum v. United States, 372 U.S. 734 (1963). If a disposition of the case is made before the empanelling of a jury, further prosecution is not precluded; but if the Attorney General has refused to obey the first court order, under the threat of a criminal contempt citation, there is little likelihood of his subsequent compliance. If the only party in contempt is the local United States attorney, and no jury has been empanelled, the Justice Department might still prosectutc. Cf. United States v. Thompson, 251 U.S. 407 (1920).

Other judicial responses may be available to deal with prosecutorial non-compliance. In the case of United States v. Cox 342 F.2d 167, 179 (5th Cir. 1965), discussed in text accompanying notes 25-29, supra, the opinion of Judges Rives, Gewin and Bell suggested that, "In the unlikely event of bad faith or irrational action ... it may be that the court could appoint counsel to prosecute the case." Although no federal court has ever attempted to appoint a private prosecutor, it remains a subject worthy of judicial and legislative scrutiny. In this regard, see Comment, Private Prosecution: $A$ Remedy for District Attorneys' Unzerarranted Inaction, 65 YALE L.J. 209 (1955).

69. One court, finding a United States attorney in criminal contempt for disobeying its order followed this course. In re Sylvester, 41 F.2d 231 (S.D.N.Y. 1930). 